\title{
AUMENTO DO REBORDO ALVEOLAR COM ENXERTO ÓSSEO: RELATO DE CASO
}

Renata TASSI, Fabrina BONADIO, Carmen Mueller STORRER

O rebordo ósseo alveolar é uma estrutura anatômica que tem como função o alojamento das raízes dos dentes e sua forma depende da presença e posicionamento dessas raízes. Uma das causas mais comuns de perda da arquitetura do rebordo alveolar pode ser conseqüência de uma periodontite, exodontias ou mesmo traumatismos. Com o intuito de restabelecer a anatomia devolvendo volume e altura óssea para a regiões edêntulas, existem os enxertos ósseos autógenos ou alógenos e materiais aloplásticos. As alternativas protéticas como pontes fixas ou os implantes osseointegrados necessitam de um rebordo alveolar com contorno anatômico e espessura óssea que devolva estética e função. O objetivo desse trabalho é apresentar o relato de caso do paciente M.R.N., sexo feminino, leucoderma, 55 anos, com o rebordo ósseo alveolar reduzido em espessura na região de pré-molares superior esquerdo devido à perda precoce desses dentes. O procedimento cirúrgico proposto foi o aumento do rebordo alveolar utilizando osso alógeno liofilizado em partículas. Assim, a técnica cirúrgica proposta, com enxerto ósseo alógeno, recuperou o contorno anatômico do rebordo e mostrou-se bastante simples de se realizada. 